\title{
DEMOLITION: TANTANGAN PELESTARIAN ARSITEKTUR KAWASAN KESAWAN MEDAN
}

\author{
Dwi Lindarto Hadinugroho \\ Departemen Arsitektur Fakultas Teknik Universitas Sumatera Utara \\ Jl. Perpustakaan St. J07 Building, Medan, 20155, Indonesia \\ *Email:dwilindarto@gmail.com
}

\begin{abstract}
Today's modern development puts the area of heritage in the classic dilemma in the management area of heritage between conservation and development of modernity. This study aims to examine how the form of demolition that occurs in architecture at the Kesawan District. Using a qualitative descriptive method through interpretative criticism evocative then this study identifying the model of demolition objects architectural heritage in the Kesawan District. This study revealed and indicating the existence of a variant form of demolition model issues are amputation, inactivity, redesign, masking/facelift, visual blurring and architecture sprawl. A number of heritage objects originality $17.14 \%$ indicates the level of concern occurred in the demolition of Kesawan District. This study can be used as a toolo of preservation action and evaluation for all stakeholders and the Medan City Government.
\end{abstract}

Keywords: Model Demolition Models, Architecture Preservation, Kesawan District.

\section{PENDAHULUAN}

Pertumbuhan awal pengembangan wilayah kota dimulai dengan perkembangan pembangunan growth centre (pusat pertumbuhan kawasan) yang kemudian pada masa sekarang menjadi kawasan yang diwariskan dalam bentuk urban artefak arsitektur bangunan bersejarah sebagai warisan budaya kota (heritage). Fisik warisan arsitektur demikian memiliki makna nilai runtutan peristiwa kesejarahan, kronologis perubahan budaya pembangunan, cantuman gaya langgam arsitektur seturut waktu, simpanan memory dinamika sosio-ekonomi spatial. Karenanya kawasan heritage selalu menjadi kawasan urban tissue yang demikian berkarakter, beridentitas tampil sebagai local competitiveness landmark kota bahkan mampu ditampilkan sebagai aset bagi pembentukan city branding (Muratovski, 2012). Perkembangan pembangunan modern masa kini menempatkan kawasan heritage tersebut dalam dilema klasik dalam pengelolaan kawasan heritage antara pelestarian berbasis identitas jati diri kota (continuous theory) atau perubahan berlandaskan pembangunan berdalih modernitas dan kemajuan peradaban kontemporer (change theory) (Papageorgeou, 1969). Dalam konteks konservasi ada hal yang dipertahankan ada hal yang diabaikan. Terdapat dua teori konservasi yaitu teori klasik konservasi yang berpandangan bahwa keberadaan nilai suatu objek tidak berkait dengan masyarakat sehingga tidak boleh mengalami perubahan apapun, Teori kedua dikenal dengan teori kontemporer yang melihat pusaka budaya berakar dari masyarakat yang menciptakan, memberi makna, dan yang memutuskan bangunan apa yang dapat dipilih sebagai bangunan pusaka budaya (Kwanda, 2013.

Kondisi dilematis pengelolaan kawasan heritage demikian berlangsung juga di Kota Medan sebuah kota primary dibangun Belanda tahun 1830-an. Perkembangan perkebunan swasta Deli Maaschappij berpengaruh terhadap pembentukan karakteristik Kota Medan sebagai Kota Kolonial dengan tatanan land use kota berdasarkan etnisitas dan status sosial. Salah satu kawasan heritage warisan Belanda adalah Kawasan penghubung Pelabuhan Belawan dan Perkebunan Deli Tua. Kesawan tumbuh sebagai 
central business district pada jamannya dengan fungsi campuran antara fungsi hunian (ruko dan fungsi komersial), perbelanjaan/retail, dan perkantoran. Kekayaan pengetahuan yang tersimpan pada Kawasan Kesawan sebagai kawasan heritage tercermin pada kemampuannya menumbuhkan minat penelitian para pengkaji dan pelestari dalam lingkup kajian antara lain keindahan facada (Matondang, 2012), keprihatinan akan perusakan skyline kawasan Kesawan sehingga menurunkan kualitas ruang kota (Marpaung, 2004). Potensi identitas fungsi Ruko khas Kesawan (Harisdani, 2004). Harapan akan tindakan nyata pelestarian melalui pemetaan peran masyarakat dan Pemerintah dalam tindak pelestarian (Akbar, 2014). Kemampuan Kawasan Kesawan sebagai pengungkap memory sosial visual (Utami, 2004). Kesemuanya bermuara kepada keprihatinan akan rendahnya perhatian terhadap kelangsungan Kawasan Kesawan bahkan Asmyta tahun 2008 dengan tajam mengusung istilah Demolition by Neglected menanggapi lemahnya sikap stakeholder kota Medan dalam tindak pelestarian Kawasan Heritage Kota Medan (termasuk Kawasan Kesawan) (Asmyta, 2008). Demolition atau peniadaan sendiri merupakan salah satu tindak pelestarian warisan arsitektur kota berupa tindakan renovasi dan perbaikan mayor terhadap suatu artefak kota bernilai sejarah, disamping tindak pelestarian lain yaitu preservasi, konservasi, revitalisasi, renovasi (Budiharjo, 1997). Demolisi adalah bagian dari tindak peniadaan melalui pengabaian atau pembiaran (neglected) menjadi kata yang menarik dalam kancah pelestarian arsitektur dimana bisa dimaknai sebagai perbuatan disengaja ataupun tidak disengaja (unconsciousness). Dalam pelaksanaan konservasi terhadap kawasan/bangunan cagar budaya, maka ada tindakan-tindakan khusus yang dilakukan dalam setiap penanganannya (Burra Charter, 1999, article 1.10), antara lain Konservasi yaitu semua kegiatan pemeliharaan suatu tempat sedemikian rupa sehingga mempertahankan nilai kulturalnya, Preservasi adalah mempertahankan bahan dan tempat dalam kondisi eksisting dan memperlambat pelapukan, Restorasi/Rehabilitasi adalah upaya mengembalikan kondisi fisik bangunan seperti sediakala dengan membuang elemen-elemen tambahan serta memasang kembali elemenelemen orisinil yang telah hilang tanpa menambah bagian baru. Rekonstruksi yaitu mengembalikan sebuah tempat pada keadaan semula sebagaimana yang diketahui dengan menggunakan bahan lama maupun bahan baru dan dibedakan dari restorasi. Adaptasi/revitalisasi adalah segala upaya untuk mengubah tempat agar dapat digunakan untuk fungsi yang sesuai, Demolisi adalah peniadaan melalui penghancuran atau perombakan suatu bangunan yang sudah rusak atau membahayakan (dan tidak dianggap sebagai langkah konservasi positif).

Pakar konservasi Forsyth pada tahun 2007 (Forsyth, 2007) secara tersirat menyatakan bahwa tindakan peniadaan melalui pengabaian mungkin saja terjadi dalam tindakan pelestarian dengan ungkapan sebagai berikut:

Every building, however humble, possesses a history, and buildings from different periods and regions are unique. All historic buildings undergo cycles of alteration in their lifetime. Typically, minor repairs are carried out periodically, with programmes of major maintenance, renovation and modification taking place at less frequent intervals. This pattern may alternate with periods of relative inactivity and perhaps neglect. Major changes are usually made to buildings to modify or extend their use, to update their style, and particularly to repair fire damage.

Terdapat beberapa penandaan ciri perubahan artefak heritage yaitu adanya kerusakan minor periodik yang memerlukan perawatan, renovasi, dan modifikasi. Pola kerusakan demikian juga dipengaruhi ketiadaan aktifitas dan pembiaran yang mungkin berakibat peniadaan. Mencermati Kawasan Kesawan yang telah ditetapkan sebagai salah satu kawasan konservasi dalam RTRW Kota Medan tahun 2008-2028 dan pemberlakuan Perda No.6 Tahun 1988 Kota Medan sejauh ini perubahan arsitektur di Kawasan Kesawan menunjukkan fenomena ke arah devitalisasi kawasan heritage. Kajian ini bertujuan mengkaji bagaimana wujud demolisi/peniadaan yang terjadi pada arsitektur di Kawasan Kesawan menjawab keprihatinan pemerhati pelestarian bahwa aktifitas demolisi/peniadaan telah benar terjadi. Kajian awal ini lebih merupakan identifikasi perubahan obyek warisan arsitektur yang dapat dimanfaatkan sebagai alat evaluasi bagi tindakan pelestarian yang akan dilakukan oleh 
stakeholder dan Pemerintah Kota Medan bagi Kawasan Kesawan.

\section{METODE PENELITIAN}

Kajian ini menggunakan metode deskriptif kualitatif berupa kritik arsitektur. Wayne Attoe menyatakan bahwa kritik arsitektur merupakan rekaman dari tanggapan terhadap fenomena lingkungan binaan (arsitektur). Tanggapan tersebut dapat bersifat positif maupun negatif dimana ditujukan untuk melakukan penyarigan (identifikasi) dan pemilahan (klasifikasi). Dalam hal ini kritik lebih kepada ungkapan pembedaan dibanding penghakiman sebagai ciri utamanya. Kritik Intepretif lebih memusatkan perhatian pada upaya menunjukkan kesan, pengingat terhadap obyek lain (referensial), pembandingan ataupun penyandingan dengan obyek lain maupun pembelaan bagi obyek kaji terhadap satu pandangan. Kritik Interpretif (Interpretive Criticism). Dalam hal ini peneliti bertindak sebagai kritikus/pengamat yang professional. Bentuk kritik cenderung subyektif dan bersifat mempengaruhi pandangan orang lain agar sejalan dengan pandangan kritikus tersebut. Dalam penyajiannya menampilkan sesuatu yang baru atau memandang sesuatu arsitektur dari sudut pandang lain. Kritik interpretatif yang digunakan adalah bersifat Evocative, menggugah pemahaman intelektual atas makna yang dikandung pada suatu bangunan. Sehingga kritik ini tidak mengungkap suatu objek itu benar atau salah melainkan pengungkapan pengalaman akan fenomena. Metode ini bisa disampaikan dalam bentuk naratif (tulisan) dan fotografis (Attoe, 1978).

\section{HASIL DAN PEMBAHASAN}

Dalam kajian ini tindakan demolisi dimaksudkan lebih sebagai tindakan penghilangan obyek dalam berbagai variasi dan wujud. Kajian secara arsitektural mengungkap model proses dan hasil teknik penghilangan atau peniadaan yang berlangsung di Kawasan Kesawan sebagai berikut:

\section{Pengabaian/pembiaran (neglected)}

Tindakan demolisi dengan model pembiaran berupa pengabaian terhadap perawatan dan perbaikan gedung warisan. Keterbatasan daya tahan bahan material bangunan terhadap terpaan iklim mempercepat terjadinya pembusukan/pelapukan (deterioration). Dalam jangka waktu singkat bangunan akan lapuk (seringkali hal ini menjadi justifikasi perobohan/demolisi bangunan warisan budaya). Di Kawasan Kesawan tercatat sejumlah 14 bangunan dibiarkan terlantar mengalami pelapukan alami (Gambar 1).

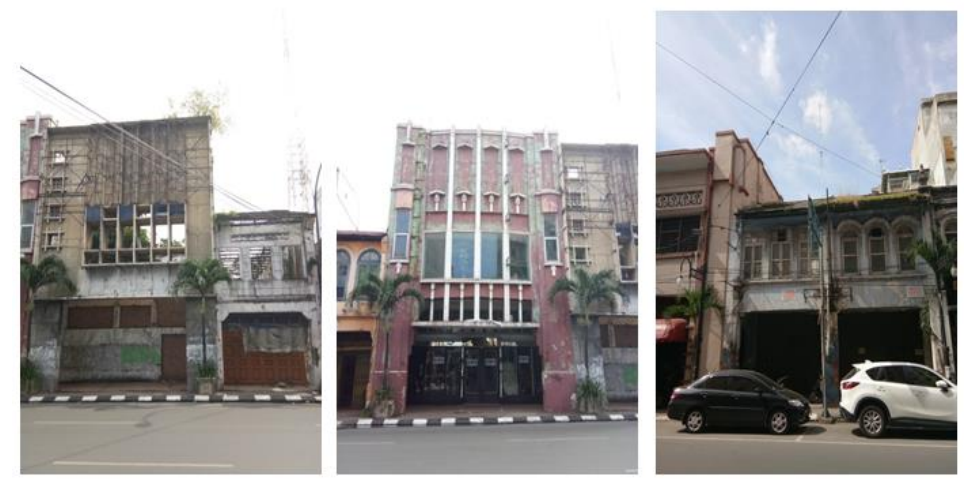

Gambar 1. Model Demolisi - Neglected

\section{Pemotongan/Amputasi}

Model amputasi meminjam istilah kedokteran berupa tindakan pemotongan sebagian obyek karena adanya penurunan fungsi. Model ini serupa dengan pengabaian dengan teknik pemisahan sebagian dari obyek untuk kemudian diganti dengan bangunan lain ataupun dilapukkan (intinya adalah peniadaan obyek). Di Kesawan terdapat sejumlah delapan bangunan menunjukkan tindakan model amputasi sebagai peniadaan obyek warisan (Gambar 2). 

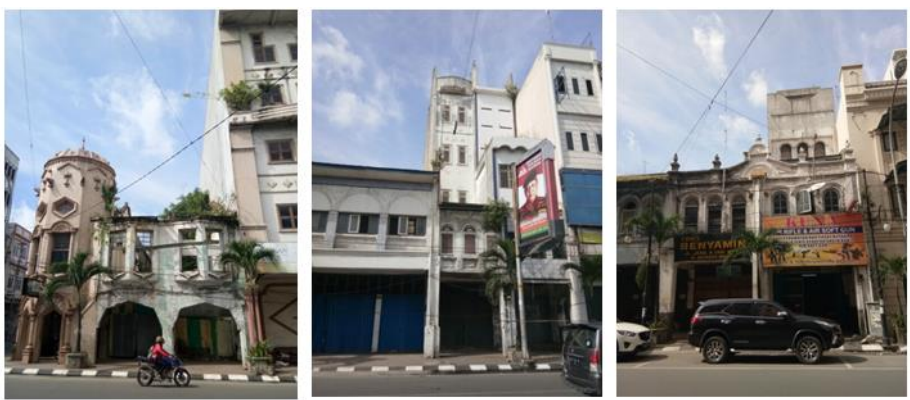

Gambar 2. Model Demolisi - Amputasi

\section{Model Devitalisasi/Inactivity}

Model inactivity adalah demolisi dengan cara meniadakan fungsi bangunan tersebut. Suatu bangunan akan berkelanjutan dengan adanya jiwa tempat (Norberg-Schultz, 1991) berupa aktifitas sehingga menjamin adanya perawatan dan renovasi. Tindakan inactivity dapat berupa peniadaan kegiatan temporer atau permanen yang ditandai dengan tidak terawatnya elemen eksterior facada maupun interior. Di Kesawan tercatat sejumlah 25 bangunan warisan tidak difungsikan secara optimal yang pada gilirannya menimbulkan ketiadaan karakter bangunan (devitalisasi) (Gambar 3).
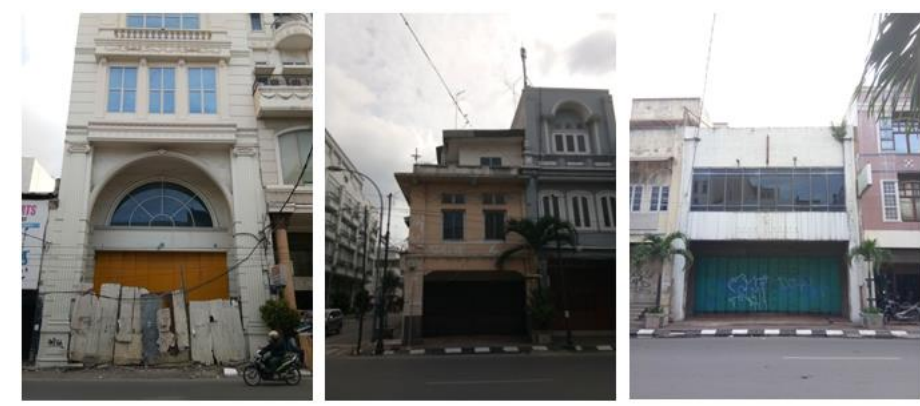

Gambar 4. Model Demolisi - Redesign

\section{Model Perubahan Arsitektur \\ (Redesign) \\ Sense of Place atau imaji Kawasan} Kesawan salah satunya terbentuk oleh keunggulan sekumpulan desain arsitektur bangunan bergaya Cina dan Kolonial. Ciri yang menunjukkan identitas kawasan ini justru memperoleh pengabaian dalam bentuk tindakan redesain berganti tampang menjadi arsitektur dengan langgam style yang tidak mencirikan dan kontekstual dengan arsitektur heritage Kesawan. Demolisi model redesain ini secara total menimbulkan demolisi terhadap citra kawasan Kesawan. Sejumlah 45 bangunan mengalami perubahan design (Gambar 5).
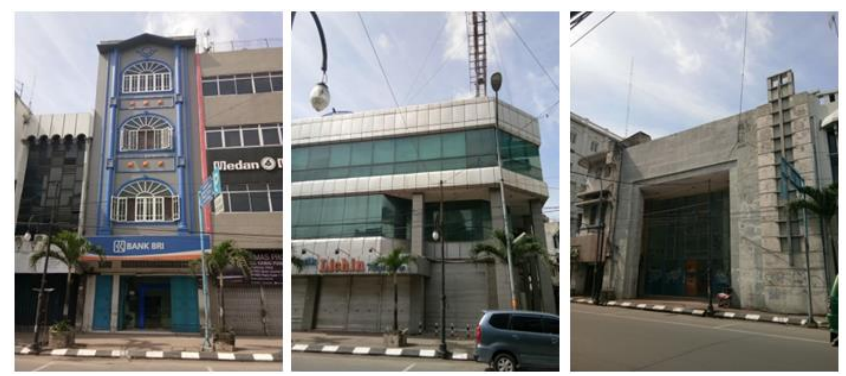

Gambar 5. Model Demolisi - Redesign

\section{Model Topengan (Masking/Facelift)}

Salah satu tindakan pembangunan facada gedung yang berpengaruh terhadap peniadaan elemen bersejarah adalah penutupan facada tata tampak arsitektur menutup hampir seluruh tampang bangunan dengan bahan bangunan modern (diistilahkan dengan masking atau facelift) (Gambar 6). Dengan demikian jati diri dan orisinalitas bangunan bersejarah mutlak tertutupi dan tergantikan dengan tampang yang 
baru memberikan efek penghilangan sama sekali terhadap tampang asli arsitektur Kesawan. Tercatat sejumlah 28 gedung berganti design rupa tampang baru berteknologi bahan kontemporer.
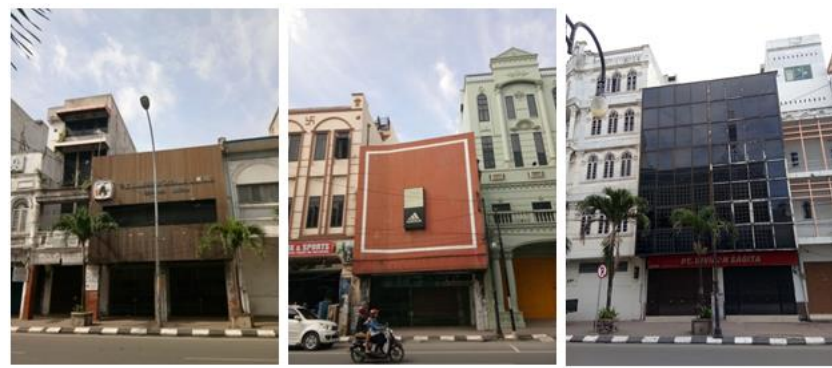

Gambar 6. Model Demolisi - Masking/Facelift

\section{Model Penghilangan Visual (Visual Blurring)}

Arsitektur mempunyai wilayah pandangan normatif dalam penikmatan visual. Dalam upaya adaptive reuse dimungkinkan adanya penambahan bangunan dengan melestarikan sebagian elemen kunci sebagai penanda kelestarian bangunan bersejarah (Marpaung, 2004) (Gambar 7).

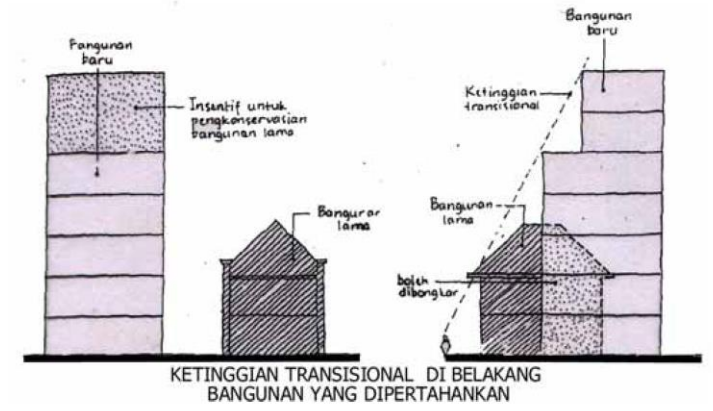

Gambar 7. Rekomendasi ketinggian Adaptive Reuse (Marpaung, 2004)

Penambahan bangunan sebagaimana rekomendasi Marpaung (2004) mempunyai keterbatasan bagi pandanagn seseorang terhadap karya arsitektur. Bangunan tinggi dengan jarak pandang terbatas hanya akan ternikmati sebatas 27 derajat oleh pengamat. Dengan demikian dapat difahami bahwa di Kesawan dahulunya hanya diperbolehkan membangun dengan ketinggian tiga lantai untuk maksimalisasi aras pandangan visual dengan penekanan ekspresi facada rendah yang menawan. Pada saat ini terdapat sekitar 14 bangunan gedung jangkung dengan ketinggian hingga 4 lantai atau lebih dengan posisi bahkan berjarak sangat dekat dengan jalan $(\mathrm{GSB}=1$ meter $)$ Model penghilangan visual ini menurunkan kualitas kenampakan facada bangunan bersejarah sekaligus menghilangkan elemen arsitektur warisan di tepian jalan Kawasan Kesawan.
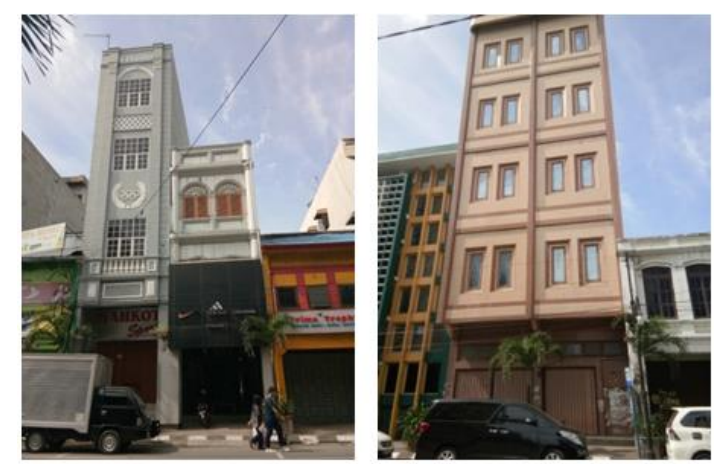

Gambar 8. Model Demolisi - Blurring Visual

\section{Model Kekacauan Arsitektural (Architecture Sprawl)}

Keberhasilan tatanan urban architecture pada suatu koridor ditentukan oleh estetika susunan tampang bangunan yang secara normatif mengikuti rhythm yang harmonis (Ching, 2008). Rhythm tersebut tersusun atas elemen tunggal maupun kelompok bangunan. Dalam tinjauan elemen imaji kawasan arsitektur bangunan dapat secara potensial membangun karakter kawasan dalam wujud suatu landmarks (Lynch, 1979). Di Kawasan Kesawan kelompok bangunan justru membentuk landmark yang tidak berkarakter Kesawan akibat desain yang tidak kontekstual. Hal demikian menyumbang demolisi terhadap identitas kawasan Kesawan yang berakibat architecture sprawl. Di Kawasan Kesawan terdapat setidaknya sepuluh kelompok bangunan besar yang potensial sebagai aksen atau landmarks namun justru potensial menimbulkan architecture sprawl (Gambar 9, dan 10).

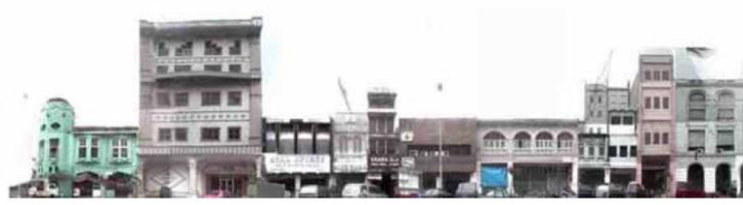

Gambar 9. Model Demolisi - Kekacauan Tampang 
Sumber: Marpaung, 2004

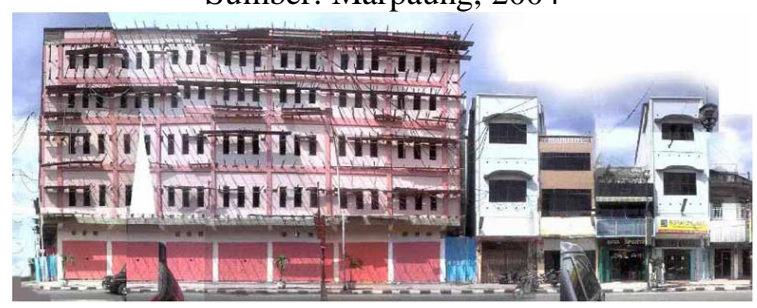

Gambar 10. Model Demolisi - Kekacauan Landmarks

Sumber: Marpaung, 2004

Identifikasi terhadap bangunan warisan arsitektur di Kawasan Kesawan menghasilkan komposisi model demolisi yang berlangsung hingga 2016 (Gambar 11).

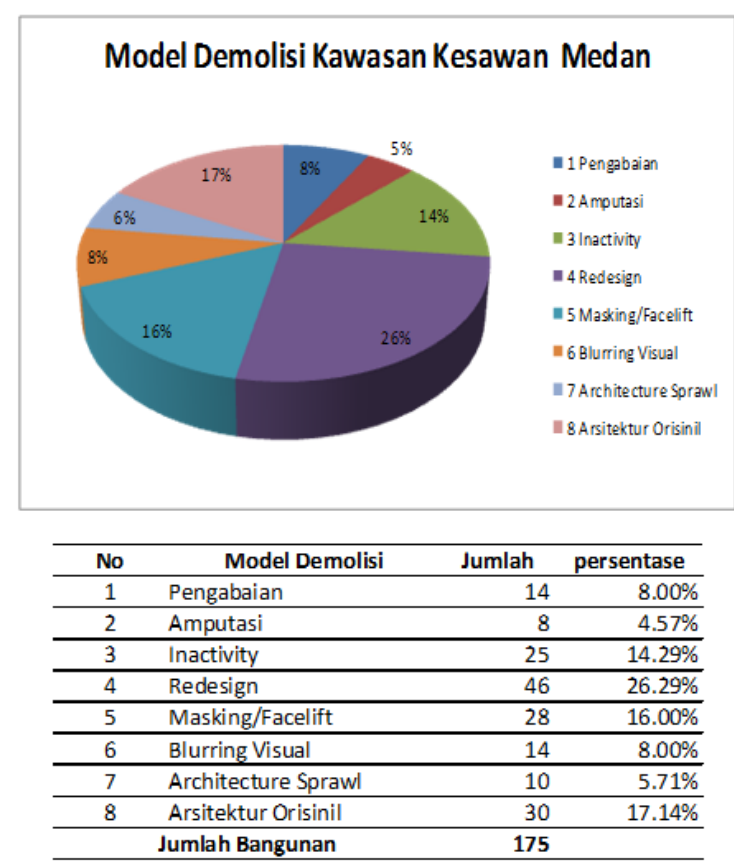

Gambar 11. Identifikasi Model Demolisi Kawasan Kesawan Medan

Dengan komposisi arsitektur warisan yang orisinil hanya asejumlah $17,14 \%$ maka dapat dikatakan bahwa Kawasan Kesawan sebagai warisan kesejarahan berada dalam kondisi yang memprihatinkan dengan terjadinya model demolisi yang berlangsung demikian masif dan terstruktur.

\section{KESIMPULAN}

Dalam perbincangan pelestarian kawasan heritage issue tentang tindakan demolisi/peniadaan tidak lagi hanya tertumpu kepada tindakan penghancuran (yang disengaja) karena demolisi juga terwujud dalam varian model pembiaran, amputasi, inactivity, redesign, masking/facelift, blurring visual dan architecture sprawl (sebagai demolisi 'tidak' sengaja). Kajian ini mengungkapkan adanya demolisi yang ternyata berlangsung dengan terstruktur dan masif terjadi pada Kawasan Kesawan. Pengungkapan ini dimaksudkan sebagai ingatan dan peringatan bagi para stakeholder kota akan adanya tantangan terhadap program pelestarian warisan kota sehingga diharapkan mampu meningkatkan kepedulian dan tidak mengabaikan pelapukan obyek warisan sebagai aset identitas kota, city branding dan local competitiveness.

\section{Ucapan Terima Kasih}

Terima kasih kepada Dr. Johannes Adijanto atas pengalaman narasi ilmiah tentang 'ignoring dan phenomenology' (Foucault dan Ricoeur) sebagai pemicu penalaran atas pelestarian Kawasan Kesawan Medan.

\section{Daftar Pustaka}

Muratovski G. (2012) The role of architecture and integrated design in city branding, Place Branding and Public Diplomacy Vol. 8, 3, 195-207. www.palgravejournals.com $/ \mathrm{pb} /$.

Papageorgeou, Alexander (1969) Continuity And Change. New York: Praeger Publishers.

Kwanda T. (2013) Otensitas takbenda dalam tradisi konservasi di Kompleks Ki Buyut Trusmi, Cirebon. Seminar Nasional Reinterpretasi Identitas Arsitektur Nusantara. Denpasar: Universitas Udayana.

Matondang K. (2012) Perubahan Fasad Bangunan Terhadap Tata Ruang Kawasan, Tugas MK. Studi Perencanaan Lingkungan Binaan II, Program Studi Teknik Arsitektur Fakultas Tenik USU Medan.

Marpaung B. (2004) Perancangan Garis Langit dan Atap Pada Kawasan Perkotaan, eUSU Repository @ usu.ac.id.Universitas Sumatera Utara. 
Harisdani D. (2004) Identitas FUngsi Ruko Kesawan, e-USU Repository @ usu.ac.id.Universitas Sumatera Utara.

Akbar M. (2014) Peran Masyarakat dan Pemerintah dalam pelestarian Bangunan Cagar Budaya di Kawasan Kesawan atau Kota Lama Bersejarah di Kota Medan, Skripsi [Yogyakarta]: Universitas Gadjah Mada.

Utami W, et al. (2004) Kajian Stimulus Collective Memory Terhadap Bangunan-Bangunan Kolonial Di Sekitar Lapangan Merdeka, e-USU Repository @ usu.ac.id.Universitas Sumatera Utara.

Asmyta S. (2008) Penghancuran Estetika Kota: Bangunan Bersejarah di Kota Medan. Mudra (Jurnal Seni Budaya), 22, 1-1.

Budiharjo, Eko (1997) Arsitektur Pembangunan dan Konservasi. Jakarta, Djambatan.

Forsyth M. (2007) Understanding historic building conservation. Oxford: Blackwell Publishing Ltd.

Attoe W. (1978) Architecture and Critical Imagination, John Wiley \& Sons, New York, pp. 89.

Norberg-Schultz Ch. (1991) Genius Loci: Towards a Phenomenology of Architecture. New York: Rizzoli.

Marpaung B. (2004) Perancangan Garis Langit dan Atap Pada Kawasan Perkotaan, eUSU Repository @ usu.ac.id. Universitas Sumatera Utara.

Ching FDK. (2008) Arsitektur Bentuk, Ruang dan Tatanan, Edisi 3, Jakarta, Erlangga.

Lynch K. (1979) The Image of The City, Cambridge, Massachusetts, The M.I.T. Press, pp. 8-9. 